\title{
KEKUASAAN DALAM TRADISI \\ PEMIKIRAN POLITIK ISLAM \\ (Refleksi Atas Pemikiran Politik Islam)
}

\author{
Usman Jafar
}

Fakultas Syariah dan Hukum Universitas Islam Negeri (UIN) Alauddin Makassar

\begin{abstract}
This study discusses the question of power in the tradition of Islamic political thought. The main issue of concern in this discussion is how power, ulama and umara in the structure of Islamic power. Through content analysis and conceptual approach, it is understood that the power is sourced from God and no one has absolute power, but that power is delegated to man as the vicegerent on earth who is commanded to uphold just government and realize common prosperity. With the concept of power like this there is no more conflict between the power of God and the human need for the existence of the government. Ulama and umara in governmental structures are those who are implied by the Qur'an as ulu al-Amr or those who govern and must be obeyed because they are composed of elected persons and meet the complementary conditions, such as, trust, courage, strength, sensible, and knowledgeable knowledge. It is hoped that they will be able to be good role model for all society. They serve as interpreters of unclear rules in the Qur'an and simultaneously oversee the "constitutionality" of governmental rules and administrators to convince the people that the rules do not violate the Shari'ah. While the umara or government apply the laws of shari'ah.
\end{abstract}

\section{Keywords:}

Power, Tradition of thought, Islamic Politics

\begin{abstract}
Abstrak
Studi ini mendiskusikani masalah kekuasaan dalam tradisi pemikiran politik Islam. Persoalan utama yang menjadi perhatian dalam diskusi ini adalah bagaiman kekuasaan, ulama dan umara dalam struktur kekuasaan Islam. Melalui analisis konten dan pendekatan konseptual diperoleh pemahaman bahwa kekuasaan itu bersumber dari Tuhan dan tidak ada seorang pun yang mempunyai kekuasaan mutlak, tetapi kekuasaan itu didelegasikan kepada manusia sebagai wakil (khalifah) di bumi yang mendapat perintah untuk menegakkan pemerintahan yang adil dan mewujudkan kesejahteraan bersama. Dengan konsep kekuasaan seperti ini tidak ada lagi pertentangan
\end{abstract}


antara kekuasaan Allah dan kebutuhan manusia akan adanya pemerinthan. Ulama dan umara dalam struktur pemerintahan adalah mereka yang diisyaratkan oleh Al-Qur'an sebagai ulu al-Amr atau mereka yang memerintah dan harus ditaati karena mereka terdiri dari orang-orang yang terpilih dan memenuhi syarat-syarat komplementer, seperti, amanah, keberanian, kekuatan, berakal sehat, dan berilmu pengetahuan. Diharapkan agar mereka mampu menjadi suri tauladan yang baik bagi segenap lapisan masyarakat. Mereka berperan sebagai penafsir terhadap aturan-aturan yang belum jelas dalam Al-Qur'an dan sekaligus sebagai pengawas "konstitusionalitas" aturan-aturan pemerintah dan para administrator demi meyakinkan rakyat bahwa aturan-aturan tersebut tidak melanggar syari'at. Sedangkan umara atau pemerintah menerapkan hukum-hukum syari'at.

Kata Kunci:

Kekuasaan, Tradisi pemikiran, Politik Islam

\section{A. PENDAHULUAN}

I stilah kekuasaan dalam tradisi pemikiran politik Islam merupakan sesuatu yang sangat penting. Karena, selain ia sebagai pondasi dan instrumen utama dalam membangun dan melanjutkan eksistensi kehidupan manusia, juga karena ia membawa imflikasi yang cukup besar terhadap sosio-politik, kultural dan peradaban manusia. Tuhan adalah sumber dan pemilik kekuasaan. Manusia hanya memperoleh delegasi kekuasaan itu dari Tuhan sebagai wakil (khalifah) di bumi. ${ }^{1}$ dalam mewujudkan kemaslahatan bersama.

Pendelegasian dan uji coba kekuasaan, untuk pertama kalinya diberikan dan dilaksanakan oleh Nabi Muhammad saw,. Meskipun ini dipandang sebagai sesuatu yang unik, karena selain sebagai Nabi dan Rasul, juga sebagai penguasa yang memegang kedaulatan dan menjadi sumber inspirasi bagi perundang-undangan Islam.

Sebagai penguasa, Nabi Muhammad saw, mengkonsolidasikan dan mengakomodir orang-orang Islam dan semua warga yang tergabung dalam satu masyarakat yang secara fisik dan politis berbeda dengan kelompok-kelompok lain. Tidak ada pengertian lain mengenai siapa yang harus memegang tampuk pimpinan dalam konfederasi semacam itu. Dan secara tegas menyebutkan Allah dan Nabi Muhamamad sebagai hakim dan sumber segenap kekuasaan dan kekuatan.

Dalam rangka konsulidasi politik, beliau berperan sebagai pemimpin bagi sebuah pemerintahan Islam yang baru lahir itu. Sebagai nabi, dan sekaligus sebagai pemegang kekuasaan, beliau meletakkan prinsip-prinsip dasar agama dan memimpin umat yang hetrogen. Kekuasaan Nabi Muhammad saw, di Madinah

\footnotetext{
${ }^{1}$ Al-Qur'an, (3): 26, 189, dan Al-Qur'an, (6): 165
} 
tidak berlangsung lama karena beliau wafat. Peristiwa wafatnya Nabi yang tidak terduga menjadi sebab larutnya masyarakat dalam ketidakpastian tentang kepemimpinan Islam selanjutnya.

Nabi sejak masih hidup, tidak pernah menyampaikan pesan atau wasiat tentang siapa yang akan menganggantikannya, melanjutkan kekuasaan politik Islam. Itulah yang menjadi persoalan yang menyita perhatian banyak pihak. Tetapi perdebatan itu kemudian berakhir dengan terpilihnya Abu Bakar sebagai pelanjut dalam melaksanakan kekuasaan, menjadi khalifah dalam sistem kekhalifahan, sekaligus menandai era "Khulafa al-Rasyidin". Masa itu merupakan cermin kejayaan Islam yang diraih dengan berbagai perangkat, dan tetap berada di bawah prinsip konstitusi Madinah.

Perebutan kekuasaan telah mewarnai perjalanan pemerintahan Islam selanjutnya, terutama pada masa pemerintahan Usman bin Affan, khalifah ke-3. Beliau dipilih oleh sekelompok dewan pemilih yang lebih dikenal dengan Ahl al-Halli Wal aqdi yang dibentuk sebelumnya oleh Umar. ${ }^{2}$ Kericuan tidak terelakan, bermuara pada sekelompok pejabat pemerintahan yang didasarkan pada favoritisme dan nepotisme. Cara ini melahirkan rasa tidak puas dan keresahanpun di kalangan masyarakat muncul yang kemudian berkembang menjadi pertikaian politik dan mencapai puncaknya pada kematian Usman.

Pertikaian politik terus berlanjut pada masa kekuasaan Ali, kemenakan Nabi dan rival Usman dalam perebutan kursi kekuasaan, kemudian dinobatkan menjadi khalifah dan mampu meraup kesetiaan dari sebagian besar umat Islam. Meski demikian, ia juga dihadapkan oleh berbagai persoalan dengan lahirnya oposisi kuat dari masyarakat, terutama dari anak turun Umaiyyah yang pernah diuntungkan pada masa Usman. Lebih dari itu, istri Nabi sendiri, Aisyah r.a diiringi dengan sebagian sahabat karib nabi, menyuarakan sikap anti Ali. Sikap ini melahirkan konflik dan kekerasan yang bermuara pada perang sipil yang berakhir dengan terbunuhnya Ali dan memunculkan kekuasaan dan pemerintahan baru yang lebih dikenal dengan kekuasaan dinasti bani Umaiyyah.

Berkaitan dengan kekuasaan yang mejadi perhatian dalam studi ini, penulis akan menganalisis dengan mengawali pada masalah kekuasaan atau kedaulatan, setelah itu baru mendiskusikan mengenai Ulama dan Umara dalam struktur Kekuasaan.

\section{B. MASALAH KEDAULATAN}

Mendiskusikan tentang kekuasaan atau kedaulatan, sebaiknya dimulai dengan melihat bagaimana ungkapan Al-Qur'an mengenai kekuasaan, dan apakah implikasi konsep Islam tentang kekuasaan yang lahir berdasarkan konstitusi ?

\footnotetext{
${ }^{2}$ Amir Siddiqi, Studies in Islamic History, (Karachi: Jam'iyatul Falah Publications, 1962), h. 40
} 
Untuk menjawab permasalahan tersebut, studi ini akan diawali lebih dahulu dengan meneliti konsep Barat tentang kekuasaan. Jien Bodeim, seorang filosof Barat memberikan definisi tentang kekuasaan, bahwa kekuasaan itu adalah suatu kekuatan tertinggi yang bersifat abadi, tidak diwakilkan atau didelegasikan, tanpa batasan atau dibatasi oleh kondisi, tidak dapat dicabut dan tidak terlukiskan. Karena kekuasaan adalah sumber hukum, maka hukum tentu tidak dapat membatasi kekuasaan tersebut. ${ }^{3}$ George Sabine mengomentari pandangan ini dengan mengatakan bahwa konsep Bodein tentang kekuasaan itu dikompromikan dengan hukum dan subyek hukum-hukum konstitusional tertentu yang tidak berasal dari pemikirannya sendiri di samping tidak dapat berubah. ${ }^{4}$

Sedangkan Thomas Hobbes (1588-1679), seorang filosuf Politik Inggris, ketika memberikan pengertian tentang kekuasaan, beliau berusaha menampilkan pendekatan yang lebih logis. Dalam bukunya, Leviathan, beliau menawarkan teori kekuasaan yang tidak dapat dibantah, mutlak, tak dapat dibagi dan tidak terbatas. ${ }^{5}$ Meskipun sejalan dengan logika, teori Habbes tersebut tidak terlepas dari sasaran kritik karena dianggap terlalu mekanistik sehingga mengesampingkan nilai-nilai manusia dan preservasi dirinya.

Sementara Jean Jacques Rousseau (1712-78), seorang filosof kebangsaan prancis menggabungkan antara teori kekuasaan Hobbes dengan teori John Locke (16231704), yang dikenal dengan "populer consent". Gabungan dua teori itu kemudian melahirkan konsep filsafat kekuasaan populer atau kekuasaan yang berasal dari kehendak umum. ${ }^{6}$ Namun, jikalau Rousseau memberikan koreksi terhadap mekanisme Hobbes, maka teorinya sendiri terperosok dalam lautan abstraksi dan kekaburan yang berlebihan.

Dengan munculnya negara-nasion (nation-state) pada abad modern, konsep kekuasaan diwarnai dengan dimensi positivistik yang menekankan eksistensi kekuasaan alamiah yang berperan sebagai sumber kekuasaan mutlak, kekuasaan itu menghendaki kepatuhan mutlak dengan dukungan mesin negara yang berupa kekuasaan tak terbatas dan semua perintahnya adalah hukum yang harus dipatuhi. ${ }^{7}$

Berbeda dengan teori kekuasaan yang dikemukakan di atas, di kalangan intelektual Islam mengemukakan beberapa teori mengenai kekuasaan. Di antaranya Teori ketuhanan, teori kekuatan, dan teori kontrak sosial. Teori ketuhanan misalnya, megatakan bahwa kekuasaan berasal dari Tuhan, penguasa bertahta atas kehendak

\footnotetext{
${ }^{3}$ Ibnu Taimiyah yang mengutip pendapat Jien Bodein dalam bukunya, Majmu'at al-Razail al-Kubra, jilid 2, (Kairo: Mutba'at Muhammad Ali Subayh, 1966), h. 94

${ }^{4}$ George Sabine, A History of Political Theory, Disuntig oleh Thomas Thorson (Hindsale: Dryden Press, 1973), h. 377

5 Thomas Hobbes, Leviathan, disunting dengan kata pengantar oleh C.B. Macpherson, (Englang: Penguin Books, 1968), h. 228-32

${ }^{6}$ Jean Jacques Rousseau, On the Social Contract, disunting oleh Roger D. Masters dan diterjemahkan oleh Judith R. Masters, (New York: St. Martin's Press, 1978), h. 341

7 John Austin, "Law. Ethies, and the State", dalam W.y. Elliot dan N.A McDo-nald, Western Political Heritage (Englewood Cliffos, N.J: Prentice-Hall, Inc,. 1949), h. 729-35
} 
Tuhan sebagai pemberi kekuasaan kepadanya. $^{8}$ Sementara teori kekuatan mengatakan, kekuasaan politik diperoleh melalui kekuatan dalam persaingan antara kelompok. Negara dibentuk oleh yang menang, dan kekuatanlah yang membentuk kekuasaan dan pembuat hukum. ${ }^{9}$

Teori di atas, juga dikemukakan Ibnu Khaldun. Bagi khaldun, manusia sebagai masyarakat memerlukan al-wazi' (pemimpin) untuk melaksanakan kekuasaan dan memperbaiki kehidupan masyarakat dan mencegah terjadinya perbuatan aniyah di antara sesama. Pemimpin diikuti karena memeiliki kekuatan dan pengaruh atas masyarakatnya. Hubungan sosial masyarakatnya berdasarkan hubungan keturunan yang disebutnya 'ashabiyat yaitu solidaritas kelompok sebagai perekat kekuatan kelompok itu. Dengan demikian suatu daulah (pemerintahan) dapat terbentuk apabilah suatu kelompok masyarakat mampu mengalahkan kelompok masyarakat lainnya, dan dengan kemenangan itu ia memperoleh kekuasaan politik. ${ }^{10}$

Lain halnya dengan teori kontra sosial. Teori ini mengatakan, kekuasaan diperoleh melalui perjanjian masyarakat. Artinya kekuasaan politik bersumber dari rakyat, dan legitimasinya melalui perjanjian masyarakat. Dengan kata lain terjadinya penyerahan kekuasaan oleh anggota masyarakat kepada seseorang atau lembaga. ${ }^{11}$

Merujuk pada ketiga teori di atas, tampaknya, Al-Baqillani, Al-Baghdadi, AlMawardi, AlJuwaini, dan Ibnu Khaldun lebih berorientasi pada paham dan teori kontra sosial. Dalam pengertian lain, sumber kekuasaan bagi mereka berasal dari masyarakat. Karena gagasan mereka tentang proses terbentuknya negara adalah atas dasar kehendak manusia sebagai mahluk sosial atau makhluk politik untuk berkumpul di suatu tempat dalam rangka kerjasama dan tolong menolong untuk memenuhi kebutuhan hidup. Tetapi tabiat manusia yang demikian mereka kaitkan keyakinan agama. Sebagai ciptaan dan kehendak Tuhan atas manusia. Dalam kerjasama itu mereka memerlukan seorang pemimpin yang mengatur urusan mereka.

Sedangkan Ibnu Abi Rabi' lebih berorientasi pada teori ketuhanan. Hal ini didasarkan pada pandangannya bahwa Allah mengangkat penguasa-penguasa bagi masyarakat. Penguasa-penguasa itu mendapat pancaran Ilahi dan menetapkan mereka dengan kemurahannya. ${ }^{12}$ Sebab ia tidak menyinggung apakah seorang penguasa yang mendapat pancaran Ilahi ditetapkan melalui pemilihan atau penunjukkan. Dengan demikian sumber kekuasaan bagi Rabi' bukan berasal dari rakyat, melainkan dari Tuhan yang melimpahkan-Nya kepada sejumlah kecil orang pilihan.

Sementara Al-Gazali mengemukakan pandangannya dengan berdasarkan pada ayat 59 surat al-Nisa yang memerintahkan orang-orang mukmin taat kepada Allah,

\footnotetext{
${ }^{8}$ Sabaruddin, Ilmu Negara Umum, (Jakarta: Pradya Paramita, 1986), h. 9

${ }^{9}$ F. Isywara, Pengantar Ilmu Politik, (Bandung: Angkasa, 1982), h. 153

${ }^{10}$ Ibnu Khaldun, Muqaddimat, (Tmp., Dar al-Fikr, t.t.), h. 139

${ }^{11}$ Deliar Noer, Pemikiran Politik di negara Barat, (Jakarta: Rajawali, 1982), h. 79

12 Munawir Sjadzali, Islam dan Tata Negara, Ajaran, Sejarah dan Pemikiran, (Jakarta: UI-Press), h76
} 
kepada Rasul-Nya dan kepada para pemimpin, dan ayat 26 surat Ali Imran yang menerangkan bahwa Allah memberikan kejaraan (kekuasaan) kepada orang yang ia kehendaki. Oleh karena itu Al-Gazali mendukung pandangan yang mengatakan bahwa kepala negara atau sultan adalah "bayang-bayang Allah di muka bumi". Dan karena itu rakyat wajib mengikuti dan mentaatinya, tidak boleh menentangnya. Atas dasar itu dalam kenyataan Tuhan memilih di antara anak Adam menjadi nabi dan pemimpin. Para nabi bertugas untuk membimbing rakyat ke jalan yang benar, dan para pemimpin mengendalikan rakyat agar tidak bermusuhan sesama mereka, dan dengan kebijakannya ia mewujudkan kemaslahatan bersama. ${ }^{13}$

Pandangan Al-Gazali di atas, mengandung pengertian bahwa kekuasaan kepala negara itu muqddas (suci). Karena itu rakyat wajib mentaati segala perintahnya. Sedangkan Ibn Taimiyah dapat dipahami pandangannya jika ia menolak doktrin syi'ah tentang penetapan, Ali sebagai imam sesudah Nabi, dan sebaliknya berarti ia menerima sistem pemilihan, dan sumber kekuasaan adalah rakyat, tetapi bila dilihat pendapatnya, bahwa makhluk adalah hamba Allah dan para pemimpin adalah wakil-wakil Allah atas hamba-hamba-Nya dan mereka juga adalah wakil-wakil dan hamba-hamba Allah atas diri mereka sendiri:, ${ }^{14}$ maka dalam dukungannya terhadap ungkapan yang mengatakan, sultan atau kepala negara adalah bayang-bayang Allah di atas bumi-Nya, ${ }^{15}$ dapat mengandung arti bahwa sumber kekuasaan baginya datang dari Tuhan.

Untuk memperluas cakrawala pengetahuan bahwa pengertian kekuasaan memiliki kriteria "kemutlakan", "ketidakterbatasan" dan "kebulatan", maka teori Islam tentang masalah yang sama diharapkan mampu memperjelas kajian ini. Setelah membandingkan keduanya, maka tampak bahwa teori Islam tentang kekuasaan, hakikatnya dan hukum yang muncul dari kekuasaan itu tidak sama dengan teori kekuasaan Barat. Ada sejumlah rujukan dalam Al-Qur'an, yang secara tegas menerangkan sumber kekuasaan dalam Islam.

Sumber kekuasaan dalam konteks ini dapat dilihat pada Al-Qur'an Surah Ali Imran (3): ayat 26 dan 189 berikut:

Pada Al-Qur'an surah Ali Imran (3): ayat 26 berbunyi:

"Katakanlah: 'Wahai Tuhan Yang mempunyai kerajaan, Engkau berikan kerajaan kepada orang yang Engkau kehendaki dan Engkau cabut kerajaan dari orang yang Engkau kehendaki. Engkau muliakan orang yang Engkau kehendaki dan Engkau hinakan orang yang Engkau kehendaki. Di tangan Engkau-lah segala kebajikan. Sesungguhnya Engkau Maha Kuasa atas segala sesuatu'. ${ }^{16}$

\footnotetext{
${ }^{13}$ Al-Gazali, Al-Tib al-Masbuk fi Nasehat Al-Muluk, (Cairo:, 1317 H), h. 40-41

${ }^{14}$ Ibnu Taimiyah op., cit., h.14

${ }^{15}$ Ibid., h. 139

${ }^{16}$ Al-Qur'an, 3: 26
} 
Dan Al-Qur'an surah Ali Imran ayat 189 berbunyi:

"kepunyaan Allah-lah kerajaan langit dan bumi, dan Allah Maha Perkasa atas segala sesuatu". ${ }^{17}$

Ayat-ayat Al-Qur'an tersebut, di samping ayat-ayat yang lain, menegaskan bahwa Allah adalah sumber segala kekuasaan. Ayat-ayat itu juga menjelaskan bahwa dalam Islam tidak ada seorang pun yang mempunyai kekuasaan mutlak seperti yang terdapat pada monarchi Hobbes atau reka-reka hukum dalam bentuk negara yang diajukan oleh John Austin. Tegasnya adalah bahwa Tuhan sendiri yang mempunyai kekuasaan itu.

Meskipun Al-Qur'an menegaskan bahwa Allah sebagai pemilik kekuasaan mutlak, namun menghendaki manusia agar mampu berperan sebagai wakil (khalifah) di muka bumi. Oleh karena itu manusia dapat mengklaim dirinya mempunyai kekuasaan tak terbatas sepanjang digunakan hanya demi memenuhi kehendak-Nya.

Perspektif di atas, di dasarkan pada ayat Al-Qur'an Surah Al-An'am (6): ayat 165 dan Surah Sad (38): ayat 26:

Al-Qur'an Surah Al-An'am (6): 165 berbunyi:

"Dan Dia Allah yang menjadikan kamu penguasa di muka bumi dan Dia meninggikan sebagian kamu atas sebagian yang lain beberapa derajat untuk mengujimu tentang apa yang diberikan-Nya kepadamu. Sesungguhnya Tuhanmu amat cepat siksaan-Nya dan sesungguhnya Dia Maha Pengampun lagi Maha Penyayang". ${ }^{18}$

Dan Al-Qur'an Surah Sad (38): 26

"Hai Daud, sesungguhnya Kami menjadikan kamu khalifah (penguasa) di muka bumi, maka berilah keputusan (perkara) di antara manusia dengan adil". ${ }^{19}$

Dengan konsep kekuasaan itu tidak ada lagi dipertentangkan antara kekuasaan Allah dan kebutuhan manusia akan adanya pemerintahan. Allah tetap berkedudukan sebagai satu-satunya pemilik segala kekuatan dan kekuasaan. Tetapi, uji coba kekuatan dan kekuasaan itu "didelegasikan kepada Nabi Muhammad saw, atau khalifah Allah di bumi yang mendapat instruksi untuk menegkkan pemerintahan yang adil". ${ }^{20}$

Pendelegasian kekuasaan kepada Nabi Muhammad sekaligus sebagai khalifahNya dalam melaksanakan kekuasaan dan pemerintahan Islam, Ibnu Taimiyah menyebut pemerintahan Islam itu sebagai "bayangan Allah di bumi". ${ }^{21}$ Pandangan

${ }^{17}$ Ibid., 3: 189

18 Al-Qur'an, 6: 165

${ }^{19}$ Ibid., 38: 26; juga 2: 30

${ }^{20}$ Majid Khadduri, War and Peace in the Law of Islam, (Baltimore: John Hopkins Press, 1955), h. 25

${ }^{21}$ Khalid Ibrahim Jindan, Teori Politik Islam: Telaah Kritis Ibnu Taimiyah Tentang Pemerintahan Islam, (Surabaya: Risalah Gusti, 1995), h. 62 
serupa juga dikemukakan oleh pemuka-pemuka bani Abbasiyah. ${ }^{22}$

Hanya saja, kekhalifahan itu berlaku sah apabila penanggung jawabannya dalam melaksanakan kehendak Allah atau syari'ah. Apabilah Allah adalah penguasa yang sebenarnya, maka syari'ah merupakan ungkapan kekuasaan itu, sedang tugas para khalifah-Nya adalah menerapkan hukum-hukum syari'at. Tugas itu tentu saja memerlukan kerjasama seluruh lapisan masyarakat dengan cara-cara yang telah ditetapkan oleh pemerintah atau penguasa.

Merujuk pada pemahaman tentang kekuasaan sebagaimana dikemukakan di atas, kekuasaan yang didelegasikan kepada manusia tidak hanya akan melaksanakan kekuasaan agama (hirasatu al-addin), tetapi mencakup pula kekuasaan politik (siayasah al-addunia) sekaligus. Oleh karena itu, kekuasaan yang dijalankan, apakah kekuasaan itu dalam bentuk dan format khalifah, imamah atau presiden. Haruslah dimaksudkan untuk mewujudkan dua kekuasaan tersebut, yakni sebagai pemimpin agama dan pemimpin politik sekaligus. ${ }^{23}$

Hal yang sama, juga dikemukakan Al-Mawardi (w. 1058), seperti yang dikutip Din Samsuddin. bahwa kekuasaan negara merupakan sebuah instrumen politik untuk meneruskan misi kenabian guna memelihara agama dan mengatur dunia. ${ }^{24}$ Pandangan ini memberikan legitimasi keagamaan terhadap lembaga kenegeraan, yakni negara dipahami sebagai lembaga politik dengan sangsi-sangsi keagamaan. Sedangkan syari'ah mendapat posisi sentral sebagai sumber legitimasi terhadap realitas politik.

\section{ULAMA DAN UMARA DALAM STRUKTUR KEKUASAAN}

Konsep kekuasaan modern cenderung untuk menobatkan nagara atau kepemimpinan politiknya dengan berbagai kekuasaan konstitusi yang besar dalam kawasan hukum dan undang-undang. Sedangkan konsep kekuasaan Islam, terutama jika dilihat dari sisi metodologi pemikiran politik, mereduksi negara sebagai suatu sarana untuk menerapkan hukum-hukum Tuhan atau syarai'ah.

Dalam hubungan ini, Ibnu Taimiyah lebih lanjut mengatakan, para pemimpin negara Islam hendaknya memusatkan perhatian bukan pada penciptaan hukum, namun implementasi hukum-hukum syari'at yang telah dirumuskan oleh Nabi Muhammad. Oleh karena semua hukum atau keputusan hukum telah disampaikan Nabi kepada umat, maka tidak perlu lagi mereka menyandarkan diri pada Imam atau kepala negara, karena Imam atau kepala negara hanyalah pelaksana segala ketetapan yang telah dirumuskan oleh Nabi Muhammad saw, ${ }^{25}$

${ }^{22}$ Suyuti Pulungan, Fiqhi Siyasah: Ajaran, Sejarah dan Pemikiran, (Jakarta: PT. RajaGrafindo Persada, 1995), h. 173

${ }^{23}$ Usman, Egalitarianisme dalam Islam: Refleksi Pemikiran Atas Hak-hak Politik Minoritas Non-Muslim di tengah-tengah Mayoritas Muslim, (Makassar, Alauddin University Press, 2014), 171

${ }^{24}$ M. Din Samsuddin dalam” politik demi Tuhan: Nasionalisme Religius di Indonesia”, (Bandung: Pustaka Hidayah, 1999), h. 46-47

${ }^{25}$ Ibnu Taimiyah op., cit., h.14 
Pandangan yang sama juga dikemukakan oleh Abu A'la Al-Maududi (w. 1979) bahwa kekuasaan yang dijalankan pemerintah tidaklah bermaksud menciptakan hukum baru, melainkan hanya mengimplementasikan hukum-hukum yang sudah ditetapkan oleh Tuhan melalui Nabi Muhammad. Negara hanya berfungsi sebagai kendaraan politik untuk menerapkan hukum-hukum Tuhan melalui syari' at-Nya. ${ }^{26}$

Meskipun pemimpin atau pemerintahan Islam tidak mempunyai peran dalam merumuskan hukum dan undang-undang, namun yang jelas bahwa tugas mengimplementasikan syari'at yang dilimpahkan kepada ulama dan umara, harus tetap dilakukan. Hal ini memperlihatkan betapa peran dan sentralnya posisi ulama dan umara dalam struktur kekuasaan. Dalam jenjang kekuasaan, ulama dipercayakan mengemban dwi fungsi, menafsirkan hukum-hukum syari'at dan merumuskan administrasi keadilan dan pemerintahan. Sedang umara mendapat tugas menunjang berlakunya hukum-hukum Tuhan dan mempertahankan kekuasaan negara.

Ulama dan umara, menurut para ahli, adalah mereka yang memerintah dalam mewujudkan hukum-hukum Tuhan demi kemaslahatan manusia. Oleh karena itu, ulama dan umara merupakan orang-orang terpilih yang memenuhi syarat-syarat komplementer, seperti: keberanian, kekuatan, memiliki pengetahuan dan berakal sehat. Diharpakan agar mereka sanggup memberikan suriteladan baik bagi segenap lapisan masyarakat, karena kebanyakan orang cenderung meniru tingkah laku para pemimpin mereka. "jika para pemimpin itu baik, maka rakyat pun akan turut baik, tetapi sebaliknya, bila mereka korup, rakyat pun ikut korup" ${ }^{27}$

Apabila 'Ulama' dan 'Umara' mengambil bagian dalam struktur kekuasaan negara, apakah skup kekuasaan itu ? Bagaimana kekuatan undang-undang, keputusan hukum dan pelaksanaannya dalam rangka memenuhi struktur kekuasaan itu “ Dan, apakah prinsip yang mengatur hubungan antara 'Ulama' dan 'Umara' ?

Jika dikaitkan dengan skup kekuasaan, maka permasalahannya menjadi sangat luas karena terkait erat dengan tujuan etis yang menjadi dasar pendirian sebuah negara, yaitu penerapan hukum Islam dan syari'at secara utuh. Ini berarti bahwa kekuasaan pemerintahan diharapkan mampu mengatur seluruh segi-segi kehidupan, baik masyarakat maupun perseorangan, dengan aturan yang memenuhi tujuan etika keagamaan masyarakat.

Pengembangan amanah pemerintahan (wulat al-umur) juga berkewajiban menegakkan hukum terhadap siapa saja yang melakukan perilaku terlarang atau mengabaikan kewajiban segaris dengan ajaran Al-Qur'an dan Sunnah. Hukumanhukuman tambahan dapat dilaksanakan dalam beberapa kasus dan, dalam kasuskasus lain, sifatnya fleksibel tergantung kepada kadar tindakan atau pengabaian tindakan itu dan kondisi berlakunya.

\footnotetext{
${ }^{26}$ Abu A'la Al-Mawdudi, "Political Theory of Islam" dalam kurshid Ahmad, (editor, Islamic Law and Contitution, (Lahore: tp.p., 1967), h. 243

${ }^{27}$ Ibnu Taimiyah, Majmu'at al-Razail al-Kubra, Op., cit., h. 170
} 
Tujuan etika syari'at dalam arti yang luas memerlukan sebuah kekuasaan yang mapan dan kuat guna mengatur berbagai kawasan yang jelas tidak agamis atau legal. Untuk mencapai tujuan etika itu, diperlukan apa yang disebut dengan " hisbah", yaitu sebuah lembaga atau wilayah, dengan mendasarkan konstitusinya pada syari'at sebagai dasar pelaksanaannya. ${ }^{28}$

Hisbah yang disebutkan di atas, regulasinya dilaksanakan oleh orang-orang di luar ulama dan umara, yakni seorang muslim yang memiliki kapabilitas, dalam arti memiliki pengetahuan dan pribadi yang mumpuni dalam menduduki atau menjabat sebagai Muhtasib atau anggota kelompok yang menunaikan tanggung jawab hisbah. Kelompok tersebut menjalankan tugas di bawah pangkat fungsional yang disebut dengan Komite Pelaksana Amar Ma'ruf dan Nahi Mungkar. ${ }^{29}$ Kewenangan komite Amar Ma'ruf dan Nahi Mungkar itu adalah mengontrol segala persoalan yang terjadi di masyarakat, termasuk pengontrol harga di pasar untuk menghindari menjamurnya monopoli, menginspeksi berbagai ukuran dan timbangan demi menjaga masyarakat dari penipuan dan mendakwahkan berbagai masalah moral dan agama kepada masyarakat. ${ }^{30}$ Sistem pelaksanaan operasional syari'ah model semacam ini, juga dianut oleh beberapa negara modern.

Untuk mereviw kembali struktur kekuasaan formal dari umara sebagaimana yang dikemukakan di muka, muncul pertanyaan bagaimana cara seseorang melaksanakan hubungan-hubungan antara berbagai fungsi pemerintahan tentang undang-undang, pelaksanaan dan keputusan hukum dalam suatu negara.

Diskusi yang dikemukakan sebelumnya, telah menjelaskan bahwa dalam metodologi pemikiran politik Islam cenderung mereduksi negara sebagai suatu instrumen untuk melaksanakan undang-undang Tuhan yang terdapat dalam AlQur'an dan Sunnah. Dengan demikian, kebijakan manusia hanya mempunyai ruang gerak yang sempit dan terbatas. Namun, dalam praktek sejarah kekuasaan Islam, fungsi eksekutif pemerintah negara Islam melebihi batas wewenangnya dengan mencengkram keberbagai wilayah yang sebenarnya berada di bawah wewenang bidang legislatif atau kehakiman. Seorang amir atau sultan misalnya, mempunyai kekuasaan untuk memutuskan hukum di berbagai kawasan yang tidak sejalan dengan hukum Tuhan, meskipun didukung pendapat ulama. Dengan dalih ulama berperan sebagai pengawas "konstitusionalitas", aturan-aturan pemerintah dan para administrator demi meyakinkan masyarakat bahwa aturan-aturan itu tidak melanggar teks-teks atau semangat syari'at. ${ }^{31}$

Kekuasaan untuk melakukan kontrol itu dinisbatkan pada ulama atau para hakim sesuai dengan status resmi mereka sebagai penafsir-penafsir kebenaran. Memang ada keyakinan bahwa prinsip-prinsip syari'at yang umum telah

\footnotetext{
${ }^{28}$ Khalid Ibrahim Jindan , Op., cit., h.65

${ }^{29}$ Abdul Wahab Khallaf, Al-Siyasah Al-Syari'yah,(Kairo: Daral-Anshar, 1977), h. 55

${ }^{30}$ Ibid.,

${ }^{31}$ Ibnu Taimiyah, al-Fatawa al-Kubra, jiid 5, h. 17
} 
menjelaskan: "segala perincian hukum tentang berbagai kasus yang relatif sekuler berasal dari penafsiran ulama dan para hakim". ${ }^{32}$ Dengan hak-hak penafsiran yang istimewa itu, para hakim mempunyai peranan penting dalam merumuskan undangundang tentang berbagai masalah. Hanya saja, kekuasaan itu selalu diawasi pemerintah sebagai eksekutif yang mempunyai hak-hak istimewa, termasuk hak untuk menunjuk atau memecat para hakim serta membatasi atau melonggarkan hak hukum mereka. ${ }^{33}$

Kendati demikian, di sepanjang sejarah pemerintahan Islam, pada umumnya para hakim sanggup mencapai suatu tingkatan independensi dalam memutuskan hukum karena rujukan akhir mereka bukan pemerintah, melainkan syari'at.

Dari apa yang dikemukakan di atas, dapat dikemukakan, bahwa fungsi yang paling penting dalam sebuah pemerintahan Islam adalah orang yang melaksanakan syari'at, baik para pemimpin politik maupun ulama. Dalam pengertian lain, merumuskan undang-undang bukan pekerjaan atau tugas umara maupun ulama, sebab Al-Qur'an dan Sunnah Nabi dengan tegas telah menjelaskannya. Akan tetapi, umara dan ulama boleh menggunakan qiyas dan $r a^{\prime} y$ yang sejalan dengan syari'at untuk memecahkan berbagai persoalan baru yang timbul. Keputusan hukum biasanya menjadi tugas para hakim yang relatif mempunyai otonomi sendiri. Prinsip paling pokok yang mengatur hubungan antara ulama dan umara dalam bidang garapan yang berbeda, namun saling berkaitan, adalah kerjasama. Andaipun terjadi berbagai perbedaan penafsiran atau jurisdiksi, maka rujukan terakhir mereka adalah Al-Qur'an dan Sunnah.

Perpaduan antara politik dan agama yang merupakan akibat langsung dari hakikat teologi Islam juga terungkap dalam kawasan teori konstitusional. Di sini pula jalinan moral dan hukum terungkap sehingga menyulitkan orang untuk menentukan titik temu antara tujuan moralitas dan permulaan hukum. Meski demikian, bagi orang Islam, perbedaan antara hukum dan moral itu nyaris kabur jika dlihat dari sudut syari'at yang dianggap begitu luas dan mencakup semua aspek kehidupan, material maupun spiritual di bawah panji-panji hukum yang suci dan mutlak.

Kekuasaan hukum terlihat pada nama yang dipilih dan diberikan kepada para pemeluknya, yakni syari'at. Kata itu berarti sebuah jalan yang lurus atau suatu cara hidup. Maka, Al-Qur'an sebagai rujukan akhir hukum Islam tidak saja berperang sebagai undang-undang perilaku keagamaan, tetapi yang lebih khusus, kitab suci itu merupakan hukum dasar dan tertinggi yang tidak dapat digolongkan sebagai konstitusi negara Islam.

Sumber hukum konstitusi Islam kedua yang tidak kala pentingnya adalah AsSunnah atau segala perkataan dan praktek kehidupan Nabi Muhammad saw, manusia yang dipilih Allah untuk menyampaikan risalah-Nya kepada semua

\footnotetext{
${ }^{32}$ Iqbal, "Political Thought In Islam", The Sociological Review (Tp., t,tp., 1955), h. 52

${ }^{33}$ Ibid., h. 24
} 
manusia. Segenap praktek kehidupan Khulafaur-Rasyidin juga termasuk As-Sunnah. Pada saat-saat tertentu terdapat kesepakatan umum yang berkembang di kalangan unsur-unsur politik Islam atau Ummah, berkaitan dengan permasalahan yang timbul dan, secara kolektif, kemudian mencapai suatu kesepakatan bulat. Inilah ijma atau konsensus yang merupakan sumber hukum non-substansi, selain sumber hukum pokok yaitu Al-Qur'an dan Sunnah.

\section{KESIMPULAN}

Dari analisis yang berkaitan dengan masalah kekuasaan, ulama dan umara dalam struktur kekuasaan sebagaimana dikemukakan di atas, dapat ditarik beberapa kesimpulan sebagai berikut: Pertama, bahwa teori kekuasaan dalam Islam, hakikatnya dan hukum yang muncul dari kekuasaan itu tidak sama dengan teori kekuasaan Barat. Dalam Islam sumber kekuasaan berasal dari Tuhan dan tidak ada seorang pun yang mempunyai kekuasaan mutlak (QS, 3:26 dan 189), hanya saja Allah mendelegasikan kekuasaan itu kepada manusia sebagai wakil Tuhan dibumi yang mendapat perintah untuk menegakkan pemerintahan yang adil dan dengan maksud untuk memakmurkan bumi dan mewujudkan kesejahteraan bersama. Dengan konsep kekuasaan seperti ini tidak ada lagi pertentangan antara kekuasaan Allah dan kebutuhan manusia akan adanya pemerinthan.

Kedua, bahwa ulama dan umara dalam struktur pemerintahan adalah mereka yang diisyaratkan oleh Al-Qur'an sebagai ulu al-Amr atau mereka yang memerintah dan harus ditaati oleh umat Islam. Kelompok ini terdiri dari orang-orang yang terpilih dan memenuhi syarat-syarat komplementer, seperti keberanian, kekuatan, berakal sehat, dan berilmu pengetahuan. Diharapkan agar mereka mampu menjadi suri tauladan yang baik bagi segenap lapisan masyarakat. Prinsip yang mengatur hubungan antara ulama dan umara, dalam metodologi pemeikiran Islam cenderung mereduksi negara sebagai suatu instrumen untuk melaksanakan undang-undang Allah yang terdapat dalam Al-Qur'an dan Sunnah. Ulama dalam struktur pemerintahan berperan sebagai penafsir terhadap aturan-aturan yang belum jelas dalam Al-Qur'an sebagai konstitusi syari'ah dan sekaligus sebagai pengawas "konstitusionalitas" aturan-aturan pemerintah dan para administrator demi meyakinkan rakyat bahwa aturan-aturan tersebut tidak melanggar syari'at. Sedangkan pemerintah mengemplementasikan aturan-aturan syari'at. 


\section{Daftar Pustaka}

Al-Qur'an,

Austin, John, "Law. Ethies, and the State", dalam W.y. Elliot dan N.A McDo-nald, Western Political Heritage Englewood Cliffos, N.J: Prentice-Hall, Inc, 1949

Sabine, George, A History of Political Theory, Disuntig oleh Thomas Thorson (Hindsale: Dryden Press, 1973

F. Isywara, Pengantar Ilmu Politik, Bandung: Angkasa, 1982

Al-Gazali, Al-Tib al-Masbuk fi Nasehat Al-Muluk, Cairo:, $1317 \mathrm{H}$

Hobbes, Thomas, Leviathan, disunting dengan kata pengantar oleh C.B. Macpherson, Englang: Penguin Books, 1968

Iqbal, "Political Thought In Islam", The Sociological Review, Tp., t,tp., 1955

Jean Jacques Rousseau, On the Social Contract, disunting oleh Roger D. Masters dan diterjemahkan oleh Judith R. Masters, New York: St. Martin's Press, 1978

Khaldun, Ibnu, Muqaddimat, Tmp., Dar al-Fikr, t.t.

Khadduri, Majid, War and Peace in the Law of Islam, Baltimore: John Hopkins Press, 1955

Khalid Ibrahim Jindan, Teori Politik Islam: Telaah Kritis Ibnu Taimiyah Tentang Pemerintahan Islam, Surabaya: Risalah Gusti, 1995

Khallaf, Abdul Wahab, Al-Siyasah Al-Syari'yah, Kairo: Daral-Anshar, 1977

Al-Mawdudi, Abu A'la, "Political Theory of Islam" dalam kurshid Ahmad, editor, Islamic Law and Contitution, Lahore: tp.p., 1967

Noer, Deliar, Pemikiran Politik di negara Barat, Jakarta: Rajawali, 1982

Pulungan, Suyuti, Fighi Siyasah: Ajaran, Sejarah dan Pemikiran, Jakarta: PT. RajaGrafindo Persada, 1995.

Sabaruddin, Ilmu Negara Umum, Jakarta: Pradya Paramita, 1986

Sjadzali, Munawir, Islam dan Tata Negara, Ajaran, Sejarah dan Pemikiran, Jakarta: UIPress

Samsuddin, M. Din, dalam" politik demi Tuhan: Nasionalisme Religius di Indonesia", Bandung: Pustaka Hidayah, 1999

Siddiqi, Amir, Studies in Islamic History, Karachi: Jam'iyatul Falah Publications, 1962

Taimiyah, Ibnu, yang mengutip pendapat Jien Bodein dalam bukunya, Majmu'at alRazail al-Kubra, jilid 2, Kairo: Mutba'at Muhammad Ali Subayh, 1966

Usman, Egalitarianisme dalam Islam: Refleksi Pemikiran Atas Hak-hak Politik Minoritas Non-Muslim di tengah-tengah Mayoritas Muslim, Makassar, Alauddin University Press, 2014

Taimiyah, Ibnu , al-Fatawa al-Kubra... jiid 5, 